\title{
IMPLEMENTATION OF CLASSICAL, MOLECULAR BIOLOGICAL AND IMMUNOENZYMATIC METHODS IN ISOLATION AND DETECTION OF Listeria monocytogenes IN FOOD
}

\author{
Brankica Z. Lakićević ${ }^{*}$, Aleksandra B. Martinović ${ }^{2}$, Tatjana M. Baltić1, Slobodan V. Lilić1 ${ }^{1}$ Branka R. \\ Borović $^{1}$, Predrag M. Ikonić ${ }^{3}$, Vesna V. Janković ${ }^{1}$ \\ ${ }^{1}$ Institute of Meat Hygiene and Technology, Kaćanskog 13, Belgrade, Serbia \\ ${ }^{2}$ Faculty of Food Technology, Food Safety and Ecology, Donja Gorica, 81000 Podgorica \\ ${ }^{3}$ University of Novi Sad, Institute of Food Technology, Bulevar cara Lazara 1, 21000 Novi Sad, Serbia
}

\begin{abstract}
${ }^{*}$ Corresponding author:
Phone: +381112650655

Fax: +381112651825

E-mail address: brankica@inmesbgd.com
\end{abstract}

\begin{abstract}
Food borne pathogens and spoilage bacteria are influencing the safety and quality of food and animal feed and can result in serious adverse effects to human and animal health as well as to the food quality. Consequently, microbiological quality control in the food industry has become the priority of the food producers and it aims towards minimizing the risks related to food pathogens and spoilage bacteria. One of the most important pathogens in the food industry is Listeria monocytogenes. Listeriosis has a significant public health and economic impact because of its high hospitalization and mortality rate. Most people infected with Listeria are hospitalized and mortality is approximately $30 \%$. Therefore it is necessary to undertake efficient control measures, especially concerning the necessity of a rapid and accurate detection of this pathogen in the food industry as well as in retail food samples.

Recently used conventional methods are often time consuming and require intensive work. However, obtained results can often be false considering the presence of viable but not cultivable microorganisms. Advances in biotechnology and bioinformatics have resulted in the development of novel testing technologies that enable tracking, more reliable and faster detection of food pathogens. Furthermore, molecular-biology methods, although still not applied routinely in everyday practice, are the promising alternative which can replace current reference methods in this area.
\end{abstract}

Key words: Listeria monocytogenes, laboratory detection methods, rapid tests.

\section{INTRODUCTION}

Listeria monocytogenes, a facultative intracellular Gram positive bacterium, can cause serious illness in humans and animals. It is associated with abortion, meningoencephalitis, and septicaemia in humans, especially in individuals at risk including pregnant women, newborn babies, the elderly and the immunocompromised (McLauchlin, 1997). In recent years, several studies reported outbreaks of listeriosis caused by L. monocyto- genes associated with consumption of different foods, particularly ready-to-eat products like soft cheese (Bannister, 1987), cooked and chilled poultry products (Barners et al., 1989), deli meat products (Jacquet et al., 1995) or hot dogs. Also, some epidemiologically monitored outbreaks have been reported (Kathariou, 2000). The increasing incidence of $L$. monocytogenes in food-borne outbreaks has led to the urgent 
need for a rapid detection system for testing food samples. Conventional microbiological methods for routine detection of L. monocytogenes include culture enrichment in liquid medium, (usually Fraser broth), plating on selective agar medium, biotyping and even serotyping. This procedure takes from 5 to 7 days. In the last 10 years, several PCR detection methods have been proposed to replace the time-consuming culture based conventional techniques. The most frequently chosen target gene is the hly $A$, encoding listeriolysin $\mathrm{O}$, and other targeted genes include the iap (invasion-associated protein), the $d t h-18$ (delayed type hypersensitivity), the 16S rRNA, an aminopeptidase coding gene and inlA (internalin operon) (Aznar and Alarcon, 2003).

\section{Conventional microbiological methods}

Conventional microbiological methods used for detecting microorganisms in food are easily adaptable, simple, practical, generally inexpensive and they can be used in quantitative and qualitative research. However, there are some limitations using conventional microbiological methods, especially when applied to the detection of pathogens. These methods are based on the growth of the target microorganisms in one or more culture media, visual detection of microbial growth and confirmation of the presence of the pathogen which usually included combination of biochemical and serological tests. The main disadvantages of conventional microbiological methods are: extremely challenging phases of analysis, subjective interpretation of results and for some pathogens long time required to carry out the analyses.

The most commonly used reference methods for the detection of Listeria spp. in food are ISO 11290 standards (ISO, 1996; EC, 1999). The U.S. Food and Drug Administration (FDA) has developed a protocol for the isolation of Listeria spp. from dairy products, seafood and vegetables (Hitchins, 2003), and the U.S. Department of Agriculture (USDA) developed a method for the isolation of these bacteria from meat and poultry products as well as from the environmental samples (USDA, 2002). Conventional method remains the "gold standard" with which other method is compared. They are usually very sensitive. These methods use selective agents and enrichment procedure to reduce the number of contaminating microorganisms and allow multiplication of L. monocytogenes.

All above mentioned protocols included homogenization and incubation of preenrichment and enrichment culture for 24 $72 \mathrm{~h}$ at $30-37^{\circ} \mathrm{C}$. Furthermore, before the 1990s, all commercially available media for the isolation of $L$. monocytogenes had low selectivity with the lack of the ability to distinguish $L$. monocytogenes from nonpathogenic species. Therefore, there is a need for the development of new and more selective media. Chromogenic media is the most used culture confirmation method because of its easy preparation and interpretation. Using chromogenic agars (ALOA, Rapid'L. mono), the presumptive identification of $L$. monocytogenes is possible after $24 \mathrm{~h}$, compared with 3-4 days using Oxford and other conventional agars (Greenwood et al., 2005).

\section{Immunoenzymatic methods}

There are various methods based on antibodies specific to Listeria available as commercial kits that have been applied in food testing for many years. However, only a few are available for the specific detection of $L$. monocytogenes. The enzyme linked immunosorbent assay is the most common antibody assay format used for pathogen detection in foods.

The enzyme immunoassays may contribute to accelerate and simplify the detection of various types of pathogens in foods and are the most commonly used because they posses several advantages: simplicity, rapidity, sensitivity, specificity and convenience as a screening method (Ky et al., 2004). ELISA methods that use an antibody immobilized to a microtitre well for antigen capture in combination with a secondary antibody coupled to an enzyme (or another 
label) to detect the capture antigen, are the most widely applied methods because they combine ease of use with the generation of rapid test results. It is easily applied, generates rapid test results and allows the use of difficult sample matrix. The success of ELISA method for detection of L. monocytogenes depends on the specificity of the antibody. Using hybridoma technology, it became possible to develop monoclonal antibodies that react only with $L$. monocytogenes (Janzten et al., 2006). There is a test which uses monoclonal antibodies that recognize the protein p60 (invasion - associated protein) encoded by the iap gene for identification of L. monocytogenes (Ky et al., 2004). By combining monoclonal antibodies recognized by this protein, it was possible to develop an ELISA system which can specifically identify $L$. monocytogenes or simply detect Listeria species. The Transia Plate Listeria monocytogenes (Diffchamb AB) method, which combine a two-step enrichment protocol and a specific Listeria monocytogenes immunoassay present specific, effective and reliable method for Listeria monocytogenes detection in food. The enrichment protocol was applicable to various food matrices, and microplate format of ELISA could be manipulated manually, or automatically. These method characteristics allow implementation in any food analysis laboratory. Another commercially available test is RIDASCREEN Listeria, sandwich enzyme immune assay for the qualitative detection of Listeria spp. from pre-enrichment cultures of food samples and swab samples from the production environment.

Automated Mini-VIDAS system, (BioMérieux, France), based on ELFA technology (The enyzme linked with fluorescent assay) combines ELISA and fluorescence detection. The VIDAS $\&$ LMO II was validated in 2002 (USDA, 2002) as a rapid method for all food products and environmental samples. It has been successfully used for the detection of stable antigens of virulent L. monocytogenes. In addition, there are other commercially available mini VIDAS tests such as VIDAS Listeria DUO for simultaneous detection of $L$. monocytogenes and other bacteria of the genus Listeria (Janzten et al., 2006) and $L M X$ for the qualitative detection of $L$. monocytogenes.

A low quantity of culture is divided by monocanal pipette, regulated to $500 \mu \mathrm{L}$, in the strip for reactive, the samples are absorbed and disposed from cone with a specified time period.

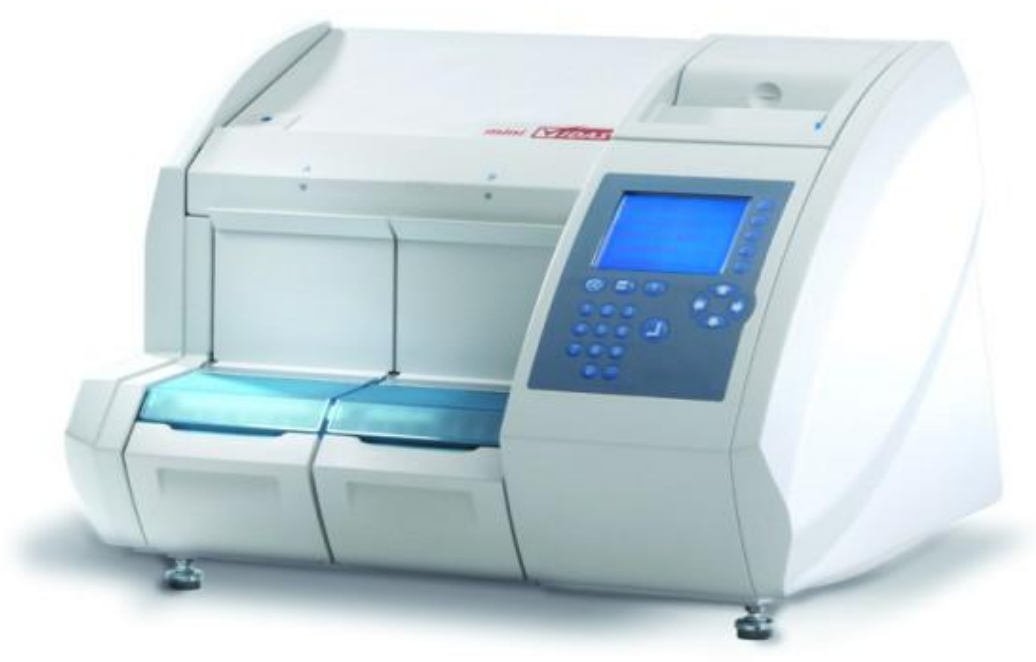

Figure1. Mini-VIDAS $®$ 
Listeria antigens that are present in the sample will interlock with anti-Listeria antibodies, which are disposed on cone walls. Unattached components of the cone are removed during washing steps. Monoclonal antibodies marked with alkaline phosphatase (conjugate) are absorbed and eliminated from the cone, coupled with any captured antigen of Listeria on cone walls.

A final washing step removes the unbound conjugate. During the final stage of detection, the substrate, 4-methyl-phosphate umberiferyl is vacuumed and removed from the cone. Enzymatic conjugate has a catalytic action on hydrolysis of this substrate with a fluorescent product (4-methyl-umbeliferone) whose fluorescence is measured at $450 \mathrm{~nm}$. When the test has been finished, the results are analyzed automatically by software. Resulting values are compared with a set of references and each sample could be positive or negative (BioMérieux, France).

The advantages of this method are: automatic printing of results at the end of the analysis, reduced time for enrichment step and detection, standardization of work (reproducibility and reliability), flexibility in operation, high sensitivity and specificity.

\section{Molecular biological methods}

Molecular biological methods have become an important support to conventional microbiological methods. Characteristic of molecular methods is rapidity, repeatability and reliability. In addition, molecular methods are independent of the variable conditions of the growth of microorganisms. Methods based on DNA analysis are simple, reliable and more cost-effective methods for identification and classification of microorganisms.

Polymerase Chain Reaction (PCR) is a method based on the selective amplification of specific fragments of DNA. The first studies of sensitivity of PCR were carried out on pure cultures (Border et al., 1990; Wang et al., 1992) and artificially contaminated food samples (Furrer et al., 1991, Wang et al,

1992.). Validation with naturally contaminated samples has also been performed in a wide range of foods (Rossen et al., 1991; Bohnert et al., 1992; Niederhauser et al., 1992, 1993). Results of these studies are not comparable with the results obtained by different procedures, in different food matrices and PCR conditions.

The most frequently chosen target gene is the $h l y A$, encoding listeriolysin $\mathrm{O}$, (Furrer et al., 1991; Bohnert et al., 1992; Niederhauser et al., 1992; Ericsson and Stålhandske, 1997; Lakicevic et al., 2010), and other target genes include the iap (invasionassociated protein) (Köhler et al., 1990; Niederhauser et al., 1992; Wang and Hong, 1999; Lakicevic et al., 2010), the dth-18 (delayed type hypersensitivity) (Wernars et al., 1991), the 16S rRNA (Wang et al., 1992) while inlA (internalin operon) (Almeida and Almeida, 2000).

Complex sample preparation and detection of PCR products using agarose gels in the final step (when a large part of the resulting PCR products are affected by degradation processes) are marked as the main disadventages of conventional PCR. In addition, conventional PCR methods only detect the presence of pathogens (Churchill et al., 2006) and are not able to make a difference between live and dead bacterial cells (O'Connor, 2003).

Multiplex PCR is a variation of the traditional PCR. This method uses multiple sets of primers to amplify a number of genes or gene fragments simultaneously. For instance, Bhagwat (2003) artificially contaminated fresh produce and used multiplex PCR to simultaneously detect $L$. monocytogenes, $S$. typhimurium, and E. coli 0157:H7. Although identification procedure is effecttive, analysis the PCR products by agarose gel electrophoresis does not make this method suitable to high-throughput screening. RealTime PCR detection is preceded by a single-step or a two-step enrichment using media of different selectivity.

These methods use different enrichment and DNA preparation approaches to reach the goal of increasing the target live cell numbers to a detectable level and dilution of dead L. monocytogenes. 


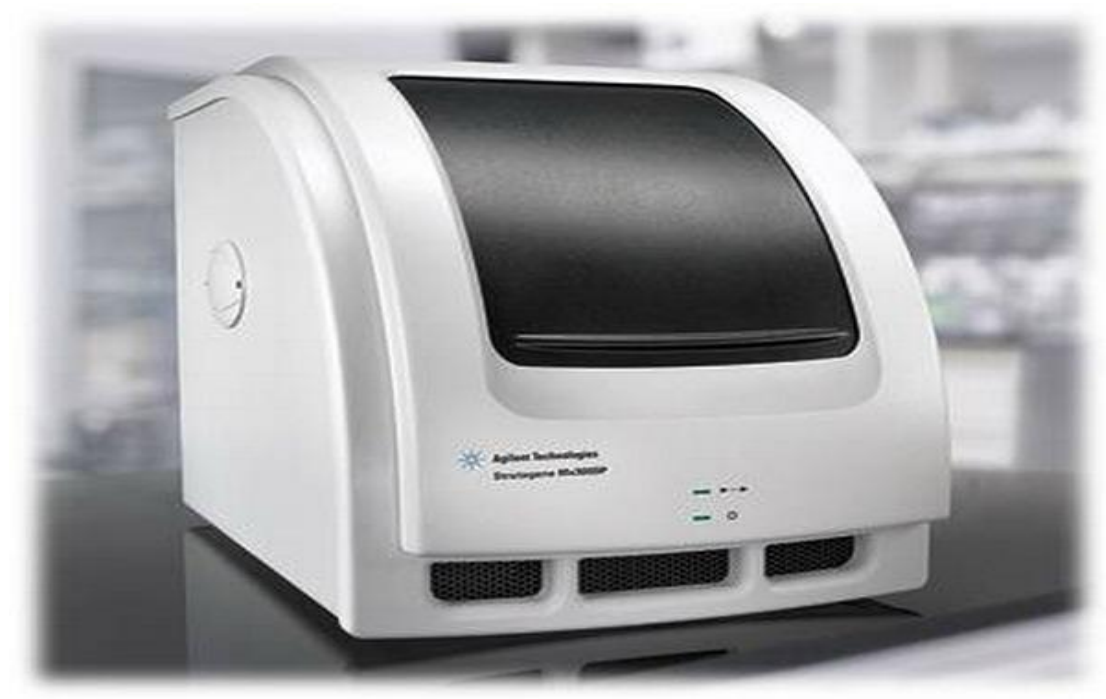

Figure 2. Real Time PCR, Stratagene Mx 3005P

Real Time PCR method detects the accumulation of amplicon during the PCR reaction. The data is then measured at the exponential phase of the reaction when the amplification DNA process is going fast, and the reaction in this phase is highly specific and precise. The principle of the method is based on detection and quantification of reporter fluorescent dye, whose emission is directly proportional to the amount of PCR product. Samples with an increasing fluorescence signal were considered positive, regardless of the internal control amplification. Samples with no increasing fluorescence signal but with amplified internal control were considered negative. Samples with no fluorescence signal for both specific target and internal control were considered inhibited. Advantages of Real Time PCR methods are analytical and diagnostic accuracy, high sensitivity, quick performance analysis, universal sample preparation for analysis, the possibility of quantitative analysis, and many others (Braguta, 2008).

Guilbaud et al. (2005) have developed a quantitative Real Time PCR method for determination of $L$. monocytogenes in an artificially made biofilms using a non-specific SYBR Green dye. Their results showed that the number of $L$. monocytogenes cells, which can be detected in biofilms is $6 \times 10^{2}$ CFU $/ \mathrm{cm}^{2}$. Rantsiou et al. (2008) developed quantitative real time PCR method for the detection, quantification and determination of the viability of $L$. monocytogenes in milk, meat, soft cheese, fermented sausages, ham and salad. Limit of quantification of method is $10^{3}-10^{4} \mathrm{cfu} / \mathrm{g}$ or $\mathrm{ml}$, while after overnight incubation at $37^{\circ} \mathrm{C}$ it was possible to detect a $10 \mathrm{cfu} / \mathrm{ml}$ or $\mathrm{g}$. In addition, in the case of the mixed culture, if $L$. innocua is present at level that is 2.5 to 3 times higher than L. monocytogenes, the identification of blue green colonies with halo, characteristic of L. monocytogenes, was not possible.

Denaturing Gradient Gel Electrophoresis (DGGE) is an electrophoretic method which can detect differences between the DNA fragments of the same size but different nucleotide sequence, based on the different melting points of DNA. This is achieved in a polyacrylamide gel in the presence of denaturing agents urea and formamide. Cocolin et al. (2002) described the direct identification of Listeria spp. and L. monocytogenes in food samples combining PCR and DGGE. The method is based on the PCR amplification of a fragment of the iap gene from the five species belonging to the 
genus and on the analysis of the PCR products obtained by denaturing gradient gel electrophoresis. Due to differences in amplified gene sequences, it is possible quickly and easy to distinguish five species of the genus Listeria as well as different serotypes within the $L$. monocytogenes species. This method can be used as a quick test to determine the presence of Listeria spp. and L. monocytogenes in food (Cocolin et al., 2002). In order to interpret data with greater accuracy, electrophoretic techniques were developed to allow better resolution of DNA fragments, such as pulsefield gel electrophoresis (PFGE), which is primarily used in conjuction with restriction enzyme (endonuclease) digests of DNA.

Pulse-Field Gel Electrophoresis (PFGE) enables separation of large DNA fragments in pulsed electric field. Total DNA of analyzed microorganism is cut with restriction enzymes, in the sites which are relatively rare in the genome. It is possible to get from 5 to 50 restriction fragments. This method is highly discriminative with high repeatability and PFGE is considered as method of choice for the molecular typing of L. monocytogenes. In 1996, Brosch et al. indicated that PFGE allows typing of $L$. monocytogenes serotype 4b. Furthermore, PFGE has been widely used in industrial plants to investigate the pathways of contamination by bacteria $L$. monocytogenes (Ojeniyi et al., 1996; Unnerstad et al., 1996; Autio et al., 1999; Giovannacci et al. 1999; Miettinen et al., 1999, 2001; Senczek et al., 2000; Fonnesbech Vogel et al., 2001; Berrang et al., 2002).

Multilocus Enzyme Electrophoresis (MEE), based on electrophoretic mobilities of soluble metabolic enzymes, has been applied in a number of epidemiological studies (Farber et al., 1991; Rørvik et al., 1995, 2000; Avery et al., 1996; Nesbakken et al., 1996; Buncic et al., 2001). This method has relatively low discriminatory power (Caugant et al., 1996).

Restriction Endonuclease Analysis (REA) is based on recognizing and cutting the total DNA of the microorganism at specific recog- nition sequences in the chromosome. As a consequence, restriction endonuclease generated fragments of different lengths. Large number of fragments, which make difficult interpretation of results is marked as the main disadventage of this method (Gerner Smidt et al., 1996).

Ribotyping is an RNA - based molecular characterization of bacteria. In ribotyping, restriction enzymes (i.e., enzymes which cut DNA at specific positions) are used to cut the genes coding for rRNA into pieces, and gel electrophoresis is used to separate the pieces by size. Genetic probes then visualize locations of different - size fragments of DNA in the gel, which appear as bands. Low power separation of strains can be overcame by using different enzymes (de Cesare et al., 2001). Automated ribotyping was used in a number of epidemiological studies (Tkáčiková et al., 2000; Norton et al., 2001; Berrang et al., 2002; Suihko et al., 2002; Aarnisalo et al., 2003; Hoffman et al., 2003), when has been successfully identified a large number of isolates.

Random Amplification of Polymorphic DNA (RAPD) is a method which uses a short arbitrary primers (Williams et al., 1990) for copying DNA fragments by PCR method in unrestricted conditions. This method is reliable and easy to perform, but the results are not always reproducible (Wernars et al, 1996). RAPD analysis allows discimination among isolates of the same serotype and also among isolates from a common source though identical profiles were obtained for some isolates belonging to the same serovar (Fonnesbech Vogel et al., 2001).

RAPD has a high power separation of $L$. monocytogenes isolates (Boerlin et al., 1995) and has been used in several epidemiological studies (Lawrence and Gilmour 1995; Giovannacci et al., 1999; Aguado et al., 2001; Fonnesbech Vogel et al., 2001).

Amplified Fragment Length Polymorphism (AFLP) is a PCR-based fingerprinting method that was originally developed for typing of plants. The AFLP technique involves 
three steps: 1) genomic DNA is cleaved with two restriction enzymes, 2) ligation of restriction site-specific adapters occurs and 3) a subset of fragments is amplified by PCR. This method is a "fingerprint" tech-nique that does not require sequence infor-mation of the studied organisms, similarly as RAPD. Reproducibility is higher than RAPD due to stricter conditions for PCR reaction. The initial step involves the digestion of the whole genome by restriction enzymes, followed by ligation and PCR reaction. The fragments obtained by AFLP, are separated on denaturing gel and visualization of the fragments can be fluorescent or autoradiography. AFLP has a high power to distinguish L. monocytogenes isolates similarly as PFGE (Fonnesbech Vogel et al., 2001; Keto Timonen et al., 2003). Genotyping which includes macro-and microarray techniques are not yet used in routine diagnosis, but initial results indicate the great importance of these methods (Ryser and Marth, 1999).

\section{Phenotypic methods}

Phenotypic methods include methods of serotyping, phage and bacteriocin typing. Serotyping is based on antigenic differences of $L$. monocytogenes strains (Seeliger and Hohne, 1979). In relation to the somatic and flagellar antigens within the $L$. monocytogenes species, may be 13 different serotypes (Schoenberg et al. 1996) of which only serotypes $1 / 2 a, 1 / 2 b$ and $4 b$ were isolated from clinical samples and food. Phage typing involves susceptibility $L$. monocytogenes isolates to the specific bacteriophage (Rocourt et al., 1985). Important characterristics of phage typing are greater discrimination power and the identification of number isolates for a relatively short period of time. A disadvantage of this method is that not all $L$. monocytogenes strains can be subjected to typing (McLauchlin et al. 1996; Ojeniyi et al., 1996). For the time being, this method has a low diagnostic value (Radojičić et al. 2011).

Bacteriocins typing involves susceptibility $L$. monocytogenes isolates to the different bac- teriocins. This method is rarely used in epidemiological studies due to poor power to distinguish isolates of $L$. monocytogenes (Curtis and Mitchell, 1992).

\section{CONCLUSIONS}

The current reference methods for the detection of $L$. monocytogenes allow the recovery of this pathogen from a variety of foods with relative ease. The introduction of chromogenic media efficiently improved the isolation of $L$. monocytogenes. Food producers and distributors have great interest in more rapid methods, which can help to bring about the desired changes in the available technology. Molecular biology, DNA based methods, particularly PCR, can be gradually replaced by the conventional methods for the detection of $L$. monocytogenes. However, there are still many problems to be solved, such as the sample preparation, elimination of the effects caused by nonspecific binding and cross hybridization and even greater sensitivity of the overall system.

\section{REFERENCES}

1. Aarnisalo, K., Autio, T., Sjöberg, A. M., Lundén, J., Korkeala, H., Suihko, M. L. (2003). Typing of Listeria monocytogenes isolates originating from the food processing industry with automated ribotyping and pulsed-field gel electrophoresis. Journal of Food Protection, 66, 249-255.

2. Aguado, V., Vitas, A. I., García Jalon, I. (2001). Random amplified polymorphic DNA typing applied to the study of cross-contamination by Listeria monocytogenes in processed food products. Journal of Food Protection, 64, 716-720.

3. Almeida, P. F. \& Almeida, R. C. C. (2000). A PCR protocol using inl gene as a target for specific detection of Listeria monocytogenes. Food Control, 11, 97-101.

4. Autio, T., Hielm, S., Miettinen, M., Sjöberg, A. M., Aarnisalo, K., Björkroth, J., Mattila Sandholm, T., Korkeala, H. (1999). Sources of Listeria monocytogenes contamination in a cold-smoked rainbow trout processing plant detected by pulsedfield gel electrophoresis typing. Applied Environmental Microbiology, 65, 150-155.

5. Avery, S. M., Hudson, J. A., Buncic, S. (1996). Multilocus enzyme electrophoresis typing of New Zealand Listeria monocytogenes isolates. International Journal of Food Microbiology, 28, 351359. 
6. Aznar, R. \& Alarcón, B. (2003). PCR detection of Listeria monocytogenes: a study of multiple factors affecting sensitivity. Journal of Applied Microbiology, 95, 958-966.

7. Bannister, B. A. (1987). Listeria monocytogenes associated with eating soft cheese. Journal of Infection, 15, 165 - 168.

8. Barners, R., Archer, P., Stack, J., Istre, G. R. (1989). Listeriosis associated with consumption of turkey franks. Morbidity and Mortality Weekly Reports, 38, 267 - 268.

9. Berrang, M. E., Meinersmann, R. J., Northcutt, J. K., Smith, D. P. (2002). Molecular characterization of Listeria monocytogenes isolated from a poultry further processing facility and from fully cooked product. Journal of Food Protection, 65, 1574-1579.

10. Bhagwat, A. A. (2003). Simultaneous detection of Escherichia coli O157:H7, Listeria monocytogenes and Salmonella strains by real-time PCR. International Journal of Food Microbiology, 84 , 217-224.

11. Boerlin, P., Bannerman, F., Ischer, J., Rocourt, J., Bille, J. (1995). Typing Listeria monocytogenes: a comparison of random amplification of polymerphic DNA with 5 other methods. Research in Microbiology, 146, 35-49.

12. Bohnert, M., Dilasser, F., Dalet, C., Mengaud, J., Cossart, P. (1992). Use of specific oligonucleotides for direct enumeration of Listeria monocytogenes in food samples by colony hybridization and rapid detection by PCR. Research in Microbiology, 143, 271-280.

13. Border, P. M., Howard, J. J., Plastow, G. S., Siggens, K. W. (1990). Detection of Listeria species and Listeria monocytogenes using polymerrase chain reaction. Letter Applied Microbiology 11, 158-162.

14. Braguta, A. (2008). Razvoj ekspres metoda za izolaciju L. monocytogenes iz prehrambenih proizvoda primenom PCR metode $\mathrm{u}$ stvarnom vremenu. Tehnologija mesa, 49, 25-29.

15. Brosch, R., Brett, M., Catimel, B., Luchansky, J. B., Ojeniyi, B., Rocourt, J. (1996). Genomic fingerprinting of 80 strains from the WHO multicenter international typing study of Listeria monocytogenes via pulsed-field gel electrophoresis (PFGE). International Journal of Food Microbiology, 32, 343.

16. Buncic, S., Avery, S. M., Rocourt, J., Dimitrijevic, M. (2001). Can food-related environmental factors induce different behaviour in two key serovars, $4 b$ and $1 / 2 \mathrm{a}$, of Listeria monocytogenes? International Journal of Food Microbiology, 65, 201-212.

17. Caugant, D. A., Ashton, F. E., Bibb, W. F., Boerlin, P., Donachie, W., Low, C., Gilmour, A., Harvey, J., Nørrung, B. (1996). Multilocus enzyme electrophoresis for characterization of Listeria monocytogenes isolates: results of an inter- national comparative study. International Journal of Food Microbiology, 32, 301-311.

18. Churchill R. L. T., Lee, H., Christopher H. J. (2006). Detection of Listeria monocytogenes and the toxin listeriolysin $\mathrm{O}$ in food. Journal of. Microbiological Methods, 64, 141-170.

19. Cocolin, L., Rantsiou, K., Cantoni, K. L., Comi, G. (2002). Direct identification in food samples of Listeria spp. and Listeria monocytogenes by molecular methods. Applied Environmental Microbiology, 68, 6273-6282.

20. Curtis, G. D. W. \& Mitchell, R. G. (1992). Bacteriocin (monocin) interactions among Listeria monocytogenes strains. International Journal of Food Microbiology, 16, 283-292.

21. de Cesare, A., Bruce, J. L., Dambaugh, T. R., Guerzoni, M. E., Wiedmann, M. (2001). Automated ribotyping using different enzymes to improve discrimination of Listeria monocytogenes isolates, with aparticular focus on serotype $4 \mathrm{~b}$ strains. Journal of Clinical Microbiology, 39, 30023005.

22. European Commission (EC) (1999). Opinion of the Scientific Committee on Veterinary Measures relating to public health on Listeria monocytogenes. European Commission. Health and Consumer Protection Directorate - General (SANCO).

23. Ericsson, H. \& Stålhandske, P. (1997). PCR detection of Listeria monocytogenes in "gravid" rainbow trout. International Journal of Food Microbiology, 35, 281-285.

24. Farber, J. M., Peterkin, P. I., Carter, A. O., Varughese, P. V., Ashton, F. E., Ewan, E. P. (1991). Neonatal listeriosis due to cross-infection confirmed by isoenzyme typing and DNA fingerprinting. Journal of Infectious Diseases, 163, 927928.

25. Fonnesbech Vogel, B., Huss, H., Ojeniyi, B., Ahrens, P., Gram, L. (2001). Elucidation of Listeria monocytogenes contamination routes in cold-smoked salmon processing plants detected by DNA-based typing methods. Applied and Environmental Microbiology, 67, 2586-2595.

26. Food and Drug Administration /Center for Food Safety and Applied Nutrition, U. S. Dept. of Agriculture / Food Safety and Inspection Service (FDA / USDA) (2001). Draft assessment of the relative risk to public health from foodborne Listeria monocytogenes among selected categories of ready to eat food (http://www.foodsafetygov/ dms/lmrisk.html)

27. Furrer, B., Candrian, U., Hoefelein, C. and Luethy, J. (1991). Detection and identification of Listeria monocytogenes in cooked sausage products and in milk by in vitro amplification of haemolysin gene fragments. Journal of Applied Bacteriology, 70, 372-379.

28. Gerner Smidt, P., Boerlin, P., Ischer, F., Schmidt, J. (1996). High-frequency endonuclease (REA) 
typing: results from the WHO collaborative study group on subtyping of Listeria monocytogenes. International Journal of Food Microbiology, 32, 313-324.

29. Giovannacci, I., Ragimbeau, C., Queguiner, S., Salvat, G., Vendeuvre, J. L., Carlier, V., Ermel, G. (1999). Listeria monocytogenes in pork slaughterring and cutting plants: use of RAPD, PFGE and PCR-REA for tracing and molecular epidemiology International Journal of Food Microbiology, 53, 127-140.

30. Greenwood, M., Willis, C., Doswell, P., Allen, G., Pathak, K. (2005). Evaluation of chromogenic media for the detection of Listeria species in food. Journal of Applied Microbiology, 99, 1340-1345.

31. Guilbaud, M., de Coppet, P., Bourion, F., Rachman, C., Prévost, H., Dousser, X. (2005). Quantitative detection of Listeria monocytogenes in biofilms by Real Time PCR. Applied and Environmental Microbiology, 71, 2190-2194.

32. Hitchins, A. D. (2003). Detection and enumeration of Listeria monocytogenes in foods. US Food and Drug Administration's Bacteriological Analytical Manual. Chapter 10

(http://www.cfsan.fda.gov/ ebam/bam-10.html)

33. Hoffman, A. D., Gall, K. L., Norton, D. M., Wiedmann, M. (2003). Listeria monocytogenes contamination patters for the smoked fish processing environment and for raw fish. Applied and Environmental Microbiology, 66, 52-60.

34. International Organization for Standardization (ISO) (1996). Microbiology of food and animal feeding stuffs - Horizontal method for the detection and enumeration of Listeria monocytogenes of Listeria monocytogenes - Part 1: Detection method. International Standard ISO 11290 - 1. International Organization for Standardization. Geneva, Switzerland.

35. Jacquet, C., Catimel, B., Brosch, R., Buchrieser, C., Dehaumont, P., Coulet, V., Lepoutre, A., Veit, P., Rocourt, J. (1995). Investigations related to the epidemic strain involved in the french listeriosis outbreak in 1992. Applied and Environmental Microbiology, 61, 2242 - 2246.

36. Janzten, M. M., Navas, J., Corujo, A., Moreno, R., Lopez, V., Martínez-Suárez, J. V. (2006). Specific detection of Listeria monocytogenes in foods using commercial methods: from chromogenic media to Real Time PCR. Spanish Journal of Agricultural Research, 4, 235-247.

37. Kathariou, S. (2000). Pathogenesis determinants of Listeria monocytogenes. In J. W. Cary, J. E, \& D. Bhatnagar, Microbial Foodborne Diseases, (pp. 295 - 314). Lancaster, PA: Technomic publishing.

38. Keto Timonen, R., Autio, T., Korkeala, H. (2003). An improved amplified fragmnet length polymorphism (AFLP) protocol for discrimination of Listeria isolates. Systematic and Applied Microbiology, 26, 236-244.
39. Köhler, S., Leimeister-Wachter, M., Chakraborty, T., Lottspeich, F., Goebel, W. (1990). The gene coding for protein p60 of Listeria monocytogenes and its use as a specific probe for Listeria monocytogenes. Infection and Immunity, 58, 19431950.

40. Ky, Y.U., Noh, Y., Park, H.J., Lee, N., Youn, M., Jung, B.Y., Youn, B. S. (2004). Use of monoclonal antibodies that recognize p60 for identification of Listeria monocytogenes. Clinical and Diagnostic Laboratory Immunology, 1, 446-4451.

41. Lakicevic, B., Stjepanovic, A., Milijasevic, M., Terzic - Vidojevic, A., Golic, N., Topisirovic, Lj. (2010). The presence of Listeria spp. and Listeria monocytogenes in a chosen food processing establishment in Serbia. Archive of Biological Science, 62, $881-887$.

42. Lawrence, L. M. \& Gilmour, A. (1995). Characterization of Listeria monocytogenes isolated from poultry products and from the poultry-processing environment by random amplification of polymerphic DNA and multilocus enzyme electrophoresis. Applied and Environmental Microbiology, 61, 2139-2144.

43. McLauchlin, J. 1997. The identification of Listeria spp. International Journal of Food Microbiology, $38,77-81$.

44. McLauchlin, J., Audurier, A., Frommelt, A., Gerner-Smidt, P., Jacquet, C., Loessner, M. J., van derMee-Marquet, N., Rocourt, J., Shah, S., Wilhelms, D. (1996). WHO study on subtyping Listeria monocytogenes: results of phage-typing. International Journal of Food Microbiology, 32, 289-299.

45. Miettinen, M. K., Björkroth, J., Korkeala, H. (1999). Characterization of Listeria monocytogenes from an ice-cream plant by serotyping and pulsed field electrophoresis. International Journal of Food Microbiology, 46, 187-192.

46. Miettinen, M. K., Palmu, L., Björkroth, K. J., Korkeala, H. (2001). Prevalence of Listeria monocytogenes in broilers at the abattoir, processing plant and the retail level. Journal of Food Protection, 64, 994-999.

47. Nesbakken, T., Kapperud, G., Caugant, D. A. (1996). Pathways of Listeria monocytogenes contamination in the meat processing industry. International Journal of Food Microbiology, 31, 161-171.

48. Niederhauser, C., Candrian, U., Höfelein, C., Jermini, M., Bühler, H. P., Lüthy, J. (1992). Use of polymerase chain reaction for detection of Listeria monocytogenes in food. Applied and Environmental Microbiology, 58, 1564-1568.

49. Niederhauser, C., Höfelein, C., Lüthy, J., Kaufmann, U., Bühler, H. P., Candrian, U. (1993). Comparison of "Gen-Probe" DNA probe and PCR for detection of Listeria monocytogenes in naturally contaminated soft cheese and semi-soft cheese. Research in Microbiology, 144, 47-54. 
50. Norton, D. M., McCamey, M. Gall, A. K., Scarlett, J. M., Boor, K. J., Wiedmann, M. (2001). Molecular studies on the ecology of Listeria monocytogenes in the smoked fish processing industry. Applied and Environmental Microbiology, 67, 198-205.

51. O'Connor, L. (2003). Detection of Listeria monocytogenes using a PCR/DNA probe assay. Methods in Molecular Biology, 216, 185-192.

52. Ojeniyi, B., Wegener, H. C., Jensen, N. E. and Bisgaard, M. (1996). Listeria monocytogenes in poultry and poultry products: epidemiological investtigations in seven Danish abattoirs. Journal of Applied Bacteriology, 80, 395-401.

53. Radojičić, S., Valčić, M., Djuričić, B. (2011). Infektivne bolesti životinja, specijalni deo, Beograd, Srbija.

54. Rantsiou, K., Alessandria, V., Urso, R., Dolci, P., Cocolin, L. (2008). Detection, quantification and vitality of Listeria monocytogenes in food as determined by quantitative PCR. International Journal of Food Microbiology, 121, 99-105.

55. Rocourt, J., Audurier, A., Courtieu, A. L., Durst, J., Ortel, S., Schrettenbrunner, A., Taylor, A. G. (1985). A multi- centre study on the phage typing of Listeria monocytogenes. Zentralblatt für Bakteriologie, Mikrobiologie und Hygiene, 259, 489497.

56. Rørvik, L. M., Aase, B., Alvestad, T., Caugant, D. A. (2000). Molecular epidemiological survey of Listeria monocytogenes in seafoods and seafoodprocessing plants. Applied and Environmental Microbiology, 66, 4779-4784.

57. Rørvik, L. M., Caugant, D. A., Yndestad, K. M. (1995). Contamination pattern of Listeria monocytogenes and other Listeria spp in a salmon slaughterhouse and smoked salmon processing plant. International Journal of Food Microbiology, 25, 19-27.

58. Rossen, L., Holmstrøm, K., Olsen, J. E., Rasmussen, O. F. (1991). A rapid polymerase chain reaction (PCR)-based assay for the identification of Listeria monocytogenes in food samples. International Journal of Food Microbiology, 14, 145152.

59. Ryser, E. T. \& Marth, E. H. (1999). Listeria, Listeriosis, and Food Safety, $2^{\text {nd }}$ ed. Marcel Dekker, Inc., New York, N.Y.

60. Schönberg, A., Bannerman, E., Courtieu, A. L., Kiss, R., McLachlin, J., Shah, S., Wilhelms, W. (1996). Serotyping of 80 strains from the WHO multicentre international typing study of Listeria monocytogenes. International Journal of Food Microbiology, 32, 279-287.

61. Seeliger, H. P. R. \& Hohne, K. (1979). Serotyping of Listeria monocytogenes and related species. In. T. Bergan \& J. R. Norris, Methods in Microbiology, vol. 13, (pp. 31-49) New York, USA.
62. Senczek, D., Stephan, R., Untermann, F. (2000). Pulsed-field gel electrophoresis (PFGE) typing of Listeria strains isolated from a meat processing plant over a 2-year period. International Journal of Food Microbiology, 62, 155-159.

63. Suihko, M. L., Salo, S., Niclasen, O., Guobjörnsdóttir, B., Torkelsson, G., Bredholt, S. A., Sjöberg, A. M., Gustavsson, P. (2002). Characterization of Listeria monocytogenes isolates from meat, poultry, and seafood industries by automated ribotyping. International Journal of Food Microbiology, 72, 137-146.

64. Tkáčiková, L., Kantíková, M., Dimitriev, A., Mikula, I. (2000). Use of the molecular typing methods toevaluate the control of Listeria monocytogenes contamination in raw milk and dairy products. Folia Microbiologica, 45, 157-160.

65. Unnerstad, H., Bannerman, E., Belle, J., Danielsson-Tham, M. L., Waak, E., Tham, W. (1996). Prolonged contamination of a dairy with Listeria monocytogenes. Netherlands Milk and Dairy Journal, 50, 493-499.

66. United States Department of Agriculture Food Safety and Inspection Sevice, Office of Public Health Science (USDA) (2002) Isolation and identification of Listeria monocytogenes from red meat, poultry, egg and environmental samples, revision 03, April 29, 2002. In: Microbiology Laboratory Guidebook

(http://www.fsis.usda.gov/OPHS/microlab/mlgboo k.htm)

67. Wang, C. \& Hong, C. (1999). Quantitative PCR for Listeria monocytogenes with colorimetric detection. Journal of Food Protection, 62, 35-39.

68. Wang, R. F., Cao, W. W., Johnson, M. G. (1992). 16S rRNA-based probes and polymerase chain reaction method to detect Listeria monocytogenes cells added to foods. Applied and Environmental Microbiology, 58, 727-736.

69. Wernars, K., Boerlin, P., Audurier, A., Russell, E. G., Curtis, G. D. W., Herman, L., van der MeeMarquet, N. (1996). The WHO multicenter study on Listeria monocytogenes subtyping: random amplification of polymorphic DNA (RAPD). International Journal of Food Microbiology, 32, 325341.

70. Wernars, K., Heuvelman, C. J., Chakraborty, T., Notermans, S. (1991). Use of the polymerase chain reaction for direct detection of Listeria monocytogenes in soft cheese. Journal of Applied Bacteriology, 70, 121-126.

71. Williams, J. G. K., Kubelik, A. R., Livak, K. J., Rafalski, J. A., Tingey, S. V. (1990). DNA polymorphism amplified by arbitrary primers useful as genetic markers. Nucleic Acid Research, 18, 6531-6535. 


\section{ПРИМЕНА КЛАСИЧНИХ, МОЛЕКУЛАРНО БИОЛОШКИХ И ИМУНОЕНЗИМСКИХ МЕТОДА У ИЗОЛАЦИЈИ И ДЕТЕКЦИЈИ БАКТЕРИЈЕ Listeria monocytogenes}

Бранкица 3. Лакићевић ${ }^{1^{*}}$, Александра Мартиновић ${ }^{2}$, Татјана М. Балтић ${ }^{1}$, Слободан В. Лилић ${ }^{1}$, Бранка Р. Боровић ${ }^{1}$, Предраг М. Иконић ${ }^{3}$, Весна В. Јанковић ${ }^{1}$

\footnotetext{
${ }^{1}$ Институт за хигијену и технологију меса, Каћанског 13, Београд, Србија

${ }^{2}$ Факултет за прехрамбене технологије, безбедност хране и екологију, Доња Горица, 81000 Подгорица

${ }^{3}$ Универзитет Нови Сад, Научни институт за прехрамбене технологије у Новом Саду, Булевар цара Лазара бр. 1, 21000 Нови Сад, Србија
}

Садржај: Патогени хране и бактерије квара утичу на безбедност и квалитет хране и хране за животиње, јер доводе до озбиљних, нежељених ефеката по здравље људи и животиња. Сходно томе, примена микробиолошке контроле у прехрамбеној индустрији је постала приоритет, која има за циљ минимизирање ризика од инфекције патогенима хране и бактеријама квара. Један од најважнијих патогена у прехрамбеној индустрији је Listeria monocytogenes. Листериоза, чији је узрочник Listeria monocytogenes, има здравствени и економски значај код људи и животиња, због високе стопе хоспитализације и смртности. Већина људи инфицираних овом бактеријом се хоспитализује, док приближно трећина инфрицираних умире. Због тога је неопходно да се предузму ефикасне мере контроле, посебно када је реч о неопходности брзог и прецизног откривања овог патогена у прехрамбеној индустрији.

Конвенционалне микробиолошке методе, захтевају интензиван рад, дуг временски период, а ипак, добијени резултати не морају бити увек поуздани (случај вијабилних микроорганизама који не подлежу култивацији). Напредак у биотехнологији и биоинформатици довели су до развоја нових технологија које омогућавају тестирање, праћење, поузданије и брже откривање патогена хране. Осим тога, молекуларно-биолошке методе, иако се до сада још не примењују у рутинској пракси, представљају обећавајућу алтернативу и могу заменити или употпунити тренутне рефрерентне методе у овој области.

Кључне речи: Listeria monocytogenes, лабораторијске детекционе методе, брзи тестови

Received: 25 December 2013

Accepted: 24 February 2014 